\title{
Analisis Framing Pemberitaan Kasus Dugaan Penistaan Agama Ustadz Abdul Somad Dalam Kompas TV
}

\author{
Novi Yanti Wulan Sari, Anisatul Afifa, Alya Nur \\ Program Studi Ilmu Komunikasi, Fakultas Ilmu Sosial dan Ilmu Politik \\ Universitas Pembangunan Nasional "Veteran" Jawa Timur \\ Email: nophysapphireblue@gmail.com, anisatul afifa@yahoo.co.id, alyabuntut23@gmail.com
}

Diterima 29 Oktober 2019 / Disetujui 24 Desember 2019

\begin{abstract}
Communication can never be separated from human life as social beings. Communication as an instrument of social interaction, which is useful for knowing and predicting the attitudes of others, and knowing one's own existence. In the beginning, communication can only be done face-to-face, but over time, communication has made the boundaries of distance and time blurred. Factors that support this things due to the presence of mass media. At the end of August 2019, the mass media was appalled with a case of alleged blasphemy of religion allegedly committed by Ustadz Abdul Somad. UAS was reported to the Police Station of NTT by Meo Brigade Organization for alleged blasphemy against the religious symbol, the cross. In this phenomenon the author is interested in examining the framing of news by Kompas TV that aims to find out how the balance of news in Kompas TV about reporting cases of alleged blasphemy by Ustadz Abdul Somad. The type of research we use is qualitative research with framing analysis methods from Zhongdang Pan and Koscki models. This study uses two types of data, primary data obtained by collecting data (documentation) from several news programs on Kompas TV that have been uploaded to Kompas TV's official YouTube channel related to cases of alleged defamation of UAS in August 2019. While secondary data were obtained through books, articles, and internet data that are relevant to the problem. The results of this study indicate that the news framing by Kompas TV shows more neutral because in its reporting Kompas $T V$ often presents several speakers from several parties with related religions to provide opinions or solutions regarding this case. Kompas TV also tends not to blame UAS as the suspect. Kompas TV prefers to use politely language when presenting the news. So it can be concluded that the framing of Kompas TV in the alleged blasphemy case by Ustadz Abdul Somad is quite balanced and does not represent the interests of any group.
\end{abstract}

Keywords : Blasphemy; Framing; Mass Media

\begin{abstract}
ABSTRAK
Komunikasi tidak pernah lepas dari kehidupan manusia sebagai makhluk sosial. Komunikasi sebagai instrumen dari interaksi sosial, yang berguna untuk mengetahui dan memprediksi sikap orang lain, serta mengetahui keberadaan diri sendiri. Pada awalnya, komunikasi hanya bisa dilakukan dengan bertatap muka, namun seiring berkembangnya zaman, komunikasi telah membuat batas ruang jarak dan waktu menjadi kabur. Faktor yang mendukung hal ini yaitu karena keberadaan media massa. Pada akhir Agustus 2019, media massa di gemparkan dengan kasus dugaan penistaan agama yang diduga dilakukan oleh Ustadz Abdul Somad. UAS dilaporkan ke kopolisian daerah NTT oleh Ormas Brigade Meo karena diduga melakukan penistaan terhadap simbol agama yaitu salib. Atas fenomena ini penulis tertarik
\end{abstract}


untuk meneliti pembingkaian berita oleh Kompas TV yang bertujuan untuk mengetahui bagaimana keberimbangan berita dalam Kompas TV mengenai pemberitaan kasus dugaan penistaan agama oleh Ustadz Abdul Somad. Jenis penulisan yang kami gunakan adalah penulisan kualitatif dengan metode analisis framing dari model Zhongdang Pan dan Koscki. Penulisan ini menggunakan dua jenis data yakni Data primer yang diperoleh dengan mengumpulkan data (dokumentasi) dari beberapa program berita di Kompas TV yang telah diunggah dalam channel youtube resmi Kompas TV yang terkait dengan kasus dugaan penistaan agama UAS pada pemberitaan Agustus 2019. Sedangkan data sekunder diperoleh melalui buku-buku, artikel, dan data-data internet yang relevan dengan masalah yang di teliti. Hasil penulisan ini menunjukkan bahwa pembingkaian berita oleh Kompas TV lebih menunjukkan tanda netral karena dalam pemberitaannya seringkali Kompas TV menghadirkan beberapa narasumber dari beberapa pihak dengan agama terkait untuk memberikan pendapat atau solusi mengenai kasus ini. Kompas TV pun cenderung tidak menyudutkan UAS selaku pihak terlapor. Kompas TV dominan menggunakan bahasa yang lebih halus saat menyuguhkan beritanya. Jadi bisa disimpulkan bahwa pemberitaan Kompas TV dalam kasus dugaan penistaan agama oleh Ustadz Abdul Somad ini tergolong berimbang dan tidak mewakili kepentingan golongan manapun.

Kata Kunci : Framing, Media Massa, Penistaan Agama

\section{PENDAHULUAN}

Pada awalnya, komunikasi hanya bisa dilakukan dengan bertatap muka dan terjadi dalam satu lingkup saja, namun seiring berkembangnya zaman, komunikasi telah membuat batas ruang jarak dan waktu menjadi kabur. Semua orang dapat berkomunikasi tanpa harus bertemu satu sama lain. Faktor yang mendukung hal ini yaitu karena keberadaan media massa. Media massa menjadi sarana manusia dalam mencari sebuah informasi. Pesan dalam media massa dikemas dalam bentuk berita. Adanya teknologi komunikasi ini memungkinkan seseorang untuk mendapatkan informasi secara cepat dan mudah. Semakin pesatnya perkembangan teknologi komunikasi, media massa pun perlahan mulai terkonvergensi menjadi suatu media dalam bentuk digital. Komputer dan internet merupakan bentuk nyata dari revolusi komunikasi yang paling banyak digunakan oleh masyarakat saat ini. Masyarakat dapat mengakses informasi dan dapat berkomunikasi dengan sesamanya melalui media yang terkoneksi dengan jaringan internet tanpa suatu hambatan. Masyarakat banyak ditopang dengan teknologi komunikasi.

Kini, internet telah menjadi tulang punggung di banyak sektor baik ekonomi atau politik. New media menawarkan variasi teknologi dan juga tantangan bagi akar keilmuan sosial (Arviani, 2013). Jurang akses informasi yang makin tinggi sepertinya tidak bisa dihindari lagi. Adanya new media membuat media massa yang telah ada pun membentuk 
suatu media baru (media online) yang terintegrasi dan melebur menjadi satu untuk diarahkan kedalam satu titik tujuan. New Media memiliki beragam jenis seperti website, blog, dan yang seringkali digunakan oleh masyarakat pada umumnya, yaitu media sosial (Sa'diyah, 2018).

Pada akhir Agustus 2019, media massa di gemparkan dengan kasus dugaan penistaan agama yang diduga dilakukan oleh Ustadz Abdul Somad. Kasus dugaan penistaan agama UAS ini bukan menjadi yang pertama di Indonesia, sebelumnya terdapat kasus serupa yang juga sangat menyita perhatian masyarakat, yaitu kasus dugaan penistaan agama yang menyeret mantan Gubernur DKI Jakarta, Basuki Tjahaja Purnama atau Ahok. Ahok dilaporkan oleh sejumlah ormas Islam karena salah satu isi pidatonya ketika ia melakukan kunjungan kerja ke kepulauan seribu pada 2016 lalu menyampaikan pendapatnya terkait surat Al Maidah ayat 5. Saat itu media massa pun berlomba lomba untuk memberitakan perkembangan kasus Ahok, termasuk Kompas TV.

Penulisan terdahulu pada Hasanah dan Budi (2017) menyatakan bahwa Kompas TV lebih banyak menampilkan tayangan berupa petikan wawancara orang-orang yang bersimpati dan mendukung Ahok, sehingga konstruksi pemberitaan sidang kasus Penistaan Agama tersebut menempatkan Ahok sebagai sosok yang tidak bersalah. Pada Anggoro (2017) juga menyatakan bahwa Kompas.com cenderung memberitakan bahwa kasus dugaan penistaan agama ini hanyalah salah satu upaya untuk menjegal Basuki Tjahaja Purnama dalam Pilkada DKI Jakarta 2017. Di sisi lain terdapat juga pemberitaan mengenai banyaknya masyarakat yang masih menaruh simpati dan dukungan kepada Basuki meski ia telah ditetapkan sebagai tersangka. Hal ini dipertegas lagi oleh Pranata (2018) yang menyatakan bahwa pemberitaan pemberitaan Kompas dalam mengkontruksi berita kasus dugaan penistaan agama terfokus pada politisasi yang dilakukan oleh para elit politik.

Hal yang sama disampaikan dalam Siregar dan Aprianti (2017), Kompas.com membuat berita yang menunjukkan aspek-aspek positif terhadap Basuki Tjahaja Purnama. Sumber-sumber yang digunakan Kompas.com sebagian besar orang-orang yang pro terhadap Basuki Tjahaja Purnama. Penulisan yang lain yaitu dalam Rohmadi dan Siswanta (2017) menyatakan bahwa Kompas.com dalam membingkai kasus dugaan penistaan agama Basuki Tjahaja Purnama terlihat Kompas mencoba membangun opini publik bahwa apa yang ia sampaikan dalam pernyataannya di Kepulauan seribu belum tentu merupakan suatu tindakan yang menistakan agama dengan menghadirkan pernyataan-pernyataan ahli. Dalam penulisan ini, Rohmadi dan Siswanta menyatakan media memiliki ideologinya masing- 
masing, pemilik media Kompas.com bukanlah bagian dari organisasi yang berbasis keagamaan di Indonesia, dan juga merupakan sebuah media yang memuat berita dengan sudut pandang masyarakat secara luas. Ideologi tersebut dapat berpengaruh di dalam proses produksi isi berita atau artikel yang secara otomatis akan menciptakan sebuah frame atau bingkai dari pemberitaan media yang bersangkutan. Secara garis besar dapat ditarik kesimpulan pada penulisan penulisan terdahulu, Kompas cenderung pro dalam pembingkaian kasus dugaan penistaan agama Ahok.

Sedangkan untuk Kasus penistaan agama kali ini bermula ketika Ustadz Abdul Somad dilaporkan ke Kepolisian Daerah Nusa Tenggara Timur oleh salah satu organisasi masyarakat di Kota Kupang pada Senin 19 Agustus 2019. Ormas yang menamakan dirinya Brigade Meo melaporkan UAS terkait dugaan penistaan terhadap simbol agama yaitu salib. Laporan ini berkenaan dengan video ceramah UAS yang viral di media sosial, video ini direkam 3 tahun lalu di Masjid An Nur Riau, pada saat itu Ustadz Abdul Somad menyinggung narasi salib dan jin kafir. Kuasa hukum Brigade Meo Yacoba mengatakan pelaporan terhadap Ustadz Abdul Somad karena ceramah yang bersangkutan meresahkan sejumlah umat Kristen dan Katolik di Indonesia.

Dalam perkembangannya, pada Rabu, 21 Agustus 2019, Ustadz Abdul Somad mendatangi Majelis Ulama Indonesia (MUI) di Jalan Proklamasi, Menteng, Jakarta Pusat untuk memberikan klarifikasi terkait video ceramahnya yang viral tersebut. Ustadz Abdul Somad mengakui bahwa memang terdapat beberapa pernyataan ceramahnya yang kemudian menyebabkan polemik. Meskipun dilaporkan, Ustadz Abdul Somad enggan meminta maaf atas ceramahnya karena menurutnya saat itu ia hanya menjawab pertanyaan dari seorang jemaah, juga ceramah tersebut berlangsung dalam kajian tertutup dalam suatu masjid di Pekanbaru, Riau. Ustadz Abdul Somad menambahkan dirinya hanya menjelaskan mengenai syariat islam, keyakinan seorang muslim yang kala itu ia mengingatkan bahwa malaikat enggan masuk ke dalam rumah seorang apabila di dalamnya ada simbol patung.

Terdapat berbagai macam tanggapan dari masyarakat. Masyarakat pun mulai terbagai dalam menyikapi kasus ini, ada pro dan kontra. Tentunya hal ini tidak luput dari peran media massa dalam membingkai kasus UAS. Salah satunya yakni Kompas TV. Kompas TV merupakan saluran televisi yang diluncurkan 09 September 2011. Meskipun tergolong media baru, namun Kompas TV telah diakui kredibilitasnya oleh publik dalam menyajikan pemberitaan pemberitaan yang faktual dan actual. Kompas bukan saja menampilkan beritanya dalam televisi saja, adanya new media membuat Kompas TV 
membuat situs berita online yaitu Kompas.com, Serta menyiarkan beritanya ke Youtube hingga Live Streaming.

Hasil dari penulisan kesimpulan jurnal diatas dan kasus yang menimpa ustad abdul somat, kedua hal itu yang menjadikan dasar penulis untuk menentukan arah penulisan ini. Semua media memiliki ideologinya masing-masing. Ideologi yang dianut oleh tiap media biasanya bergantung pada pemilik media itu sendiri. Sebagaimana diketahui bahwa pemilik dari Kompas TV, Jakob Oetama, merupakan penganut agama Katolik, yang dalam kasus dugaan Penistaan agama UAS ini agama Kristen Katolik merupakan agama yang disudutkan oleh Ustadz Abdul Somad dalam ceramahnya.

Dengan mengadakan penulisan yang berjudul "Analisis Framing Pemberitaan Kasus Dugaan Penistaan Agama Ustadz Abdul Somad dalam Kompas TV “ penulis tertarik untuk mengetahui apakah dalam pemberitaan kasus dugaan penistaan agama UAS ini Kompas TV tetap berimbang atau mempunyai kepentingan tertentu. Sehingga tujuan dari penulisan ini yaitu untuk mengetahui bagaimana keberimbangan pembingkaian berita dalam Kompas TV mengenai pemberitaan kasus dugaan penistaan agama oleh Ustadz Abdul Somad. Dengan tujuan tersebut, penulis berharap penulisan ini dapat memberikan manfaat agar pembaca dapat mengetahui kenetralan dan keberimbangan pemberitaan Kompas TV dalam kasus dugaan penistaan agama Ustadz Abdul Somad.

\section{METODE PENELITIAN}

Jenis penelitian yang kami gunakan adalah penelitian kualitatif dengan metode analisis framing. Sifat penelitian ini adalah deskriptif analisis yang bertujuan untuk mendeskripsikan karakteristik pemberitaan di Kompas TV. Penulisan ini mengidentifikasi dan menganalisa objek penulisan dengan menjawab permasalahan.

Penulis memutuskan untuk menggunakan dua jenis data dalam menyusun penulisan ini yakni data primer dan sekunder. Data primer yang digunakan adalah data yang diperoleh secara langsung dari media yang dikaji, yaitu mengumpulkan data (dokumentasi) dari beberapa program berita di Kompas TV yang telah diunggah dalam channel youtube resmi Kompas TV yang terkait dengan kasus dugaan penistaan agama yang diduga dilakukan oleh Ustadz Abdul Somad pada pemberitaan Agustus 2017. Sedangkan data sekunder diperoleh melalui buku-buku, artikel, dan data-data internet yang relevan dengan masalah yang di teliti. 
Penulisan ini masuk ke dalam paradigma atau pendekatan konstruksionis. Paradigma ini mempunyai posisi dan pandangannya tersendiri terhadap media dan teks berita yang dihasilkanya. Pandangan ini mengatakan bahwa masyarakat tidak lain adalah produk dari manusia dan juga sebaliknya manusia adalah hasil atau produk dari masyarakat. Realitas bukanlah sesuatu yang objektif, realitas yang ada dalam pemikiran manusia merupakan kontruksi atau bentukan dari manusia itu sendiri. Pendekatan ini menekankan pada politik pemaknaan dan proses bagaimana seseorang membuat gambaran tentang realitas. Makna bukanlah sesuatu yang absolut, konsep statik yang ditemukan dalam suatu pesan. Makna adalah suatu proses aktif yang ditafsirkan seseorang dalam suatu pesan. (Eriyanto, 2005).

Dalam penulisan ini penulis menggunakan metode analisis framing oleh Zhongdang Pan dan Gerald M. Kosicki. Analisis framing dipakai untuk melihat bagaimana media mengkonstruksi realitas. Analisis ini juga digunakan untuk melihat bagaimana peristiwa dipahami dan dibingkai oleh media (Eriyanto, 2002). Ada dua esensi framing utama, yakni bagaimana peristiwa dimaknai dan bagaimana fakta ditulis. Analisis Framing secara sederhana dapat digambarkan sebagai analisis untuk mengetahui bagaimana realitas (peristiwa, aktor, kelompok atau apa saja) dibingkai oleh media. Pembingkaian tersebut tentu saja melalui proses konstruksi. Hasilnya, pemberitaan media pada sisi tertentu atau wawancara dengan orang tertentu. Semua elemen tersebut tidak hanya bagian dari teknik jurnalistik, tetapi menandakan bagaimana peristiwa dimaknai dan ditampilkan. Model analisis framing dari Pan dan Kosicki merupakan salah satu model dari konsepsi framing yang paling popular dan paling banyak digunakan. Dalam buku Analisis Framing oleh Eriyanto (2007:252), analisis model ini di definisikan sebagai "proses membuat pesan lebih menonjol, menempatkan informasi lebih daripada yang lain sehingga khalayak lebih tertuju pada pesan tersebut."

Konsepsi framing dari Pan dan Kosicki tersebut menggambarkan secara luas bagaimana peristiwa dimaknai dan ditandakan oleh wartawan. Perangkat analisis framing model Pan dan Kosicki dibagi ke dalam 4 perangkat yaitu Sintaksis, Skrip, Tematik, dan Retoris. Keempat struktur tersebut memiliki arti :

\section{Struktur Sintaksis}

Sintaksis berhubungan dengan bagaimana wartawan menyusun peristiwa, pernyataan, opini, kutipan, pengamatan atas peristiwa kedalam bentuk susunan umum 
berita. Struktur sintaksis ini dengan demikian dapat diamati dari bagan berita (Lead yang dipakai, latar, headline, kutipan yang diambil, dan sebagainya). Intinya, ia mengamati bagaimana wartawan memahami peristiwa yang dilihat dari cara ia menyusun fakta kedalam bentuk umum berita.

\section{Struktur Skrip}

Skrip berhubungan dengan bagaimana wartawan mengisahkan atau menceritakan peristiwa kedalam bentuk berita. Struktur ini melihat bagaimana strategi cara bercerita atau bertutur dipakai oleh wartawan dalam mengemas peristiwa kedalam bentuk berita.

\section{Struktur Tematik}

Tematik berhubungan dengan bagaimana wartawan mengungkapkan pandangannya atas peristiwa kedalam proposisi, kalimat atau hubungan antarkalimat yang membentuk teks secara keseluruhan. Struktur ini akan melihat bagaimana pemahaman itu diwujudkan dalam bentuk yang lebih kecil

\section{Struktur Retoris}

Retoris berhubungan dengan bagaimana wartawan menekankan arti tertentu ke dalam berita. Struktur ini akan melihat bagaimana wartawan memakai pilihan kata, idiom, grafik, dan gambar yang dipakai bukan hanya mendukung tulisan, melainkan juga menekankan arti tertentu kepada pembaca. Dengan demikian kecenderungan atau kecondongan wartawan atau insttitusi media dalam memahami suatu peristiwa dapat diamati dari keempat struktur tersebut (Eriyanto, 2005).

\section{HASIL DAN PEMBAHASAN Hasil Penelitian}

Hasil penelitian ini menunjukkan bahwa pembingkaian berita oleh Kompas TV lebih menunjukkan tanda netral karena dalam pemberitaannya seringkali Kompas TV menghadirkan beberapa narasumber dari beberapa pihak dengan agama terkait untuk memberikan pendapat atau solusi mengenai kasus ini. Sehingga Kompas tidak terlihat berpihak ke siapapun. Berita berita di Kompas TV ditayangkan secara berkesinambungan sehingga penonton bisa melihat perkembangan kasus ini dari waktu ke waktu. Jika dikaji dari naskah skrip yang dibacakan oleh Anchor atau reporter, Kompas TV pun cenderung tidak menyudutkan UAS selaku pihak terlapor. Kompas TV dominan menggunkan bahasa 
yang lebih halus saat menyuguhkan beritanya. Kompas TV juga melakukan penekanan penekanan terhadap isi berita seperti menambahkan stock foto, video, dan data data lain agar berita tersebut lebih valid. Jadi bisa disimpulkan bahwa pemberitaan Kompas TV dalam kasus dugaan penistaan agama oleh Ustadz Abdul Somad ini tergolong berimbang dan tidak mewakili kepentingan golongan manapun.

\section{Pembahasan}

\section{Analisis Berita 1}

Nama program : Kompas Malam

Judul : Viral Video Ceramah, GMKI Laporkan UAS

Tabel 1. Analisis berita 1

\begin{tabular}{|c|c|}
\hline Struktur & Analisis \\
\hline Sintaksis & $\begin{array}{l}\text { Berita yang ditampilkan pada segmen Kompas Malam memfokuskan } \\
\text { bagaimana pelaporan kasus UAS yang dilakukan oleh GMKI. Namun } \\
\text { terdapat kutipan pelapor yang berkata "Point kita tujuannya adalah } \\
\text { menenangkan ketertiban social, public, masyarakat. Sehingga laporan ini } \\
\text { tujuannya untuk menjaga persatuan dan kesatuan bangsa kita" } \\
\text { berdasarkan kutipan pelapor yang ditayangkan, Kompas TV walaupun } \\
\text { memberitakan kasus yang diduga penistaan agama namun tetap } \\
\text { menunjukkan sisi positif dari alasan pelapor untuk mempolisikan UAS. }\end{array}$ \\
\hline Skrip & $\begin{array}{l}\text { Pemberitaan ini menekankan pada what (apa) apa yang terjadi, yaitu } \\
\text { pelaporan terkait kasus penistaan agama oleh UAS. who (siapa) siapa } \\
\text { pihak terkait, yaitu pelapor (ketuaa GMKI) dan terlapor (Ustadz Abdul } \\
\text { Somad). Dan yang paling dibahas yaitu Why (mengapa) mengapa pihak } \\
\text { pelapor melaporkan Ustadz Abdul Somad. }\end{array}$ \\
\hline Tematik & $\begin{array}{l}\text { Kompas TV menggunakan kata "diduga" yang bisa diartikan sebagai } \\
\text { "memperkirakan". Dengan kata lain kompas tidak menuduh secara } \\
\text { langsung bahwa UAS sebagai pihak yang bersalah. Selain itu Kompas TV } \\
\text { menggunakan kalimat menghina symbol agama" biasanya kita } \\
\text { mendengar kata "penistaan agama" namun kali ini Kompas TV } \\
\text { menggunakan kalimat "menghina simbol agama" penggunaan kalimat }\end{array}$ \\
\hline
\end{tabular}




\begin{tabular}{|l|l|}
\hline \multirow{2}{*}{$\begin{array}{l}\text { tersebut memudahkan orang awam karena berita ini merupakan berita } \\
\text { yang pertama kali ditayangkan Kompas TV, Diibanding kalimat } \\
\text { "penistaan agama", "penghinaan simbol agama lebih mudah dipahami } \\
\text { oleh semua kalangan di masyarakat. }\end{array}$} \\
\hline Retoris & $\begin{array}{l}\text { Untuk menambah nilai dan kevalidan berita, Kompas TV menampilkan } \\
\text { video ketua GMKI yang membawa surat pelaporan atas kasus terkait. }\end{array}$ \\
\hline
\end{tabular}

\section{Analisis Berita 2}

Nama program : Kompas Siang

Judul : Polemik Ceramah Ustadz Abdul Somad

Tabel 2. Analisis berita 2

\begin{tabular}{|l|l|}
\hline \multicolumn{1}{|c|}{ Struktur } & \multicolumn{1}{|c|}{ Analisis } \\
\hline Sintaksis & $\begin{array}{l}\text { Pemberitaan mengenai Ustadz Abdul Somad yang diberitakan didalam } \\
\text { media kompas. Dengan judul “ Polemik Ceramah Ustadz Abdul Somad" } \\
\text { menekankan bagaimana inti permasalahan yang terkait didalam kasus } \\
\text { yang diduga penistaan agama. Mulai dari kronologis pelaporan yang } \\
\text { dilaporkan oleh gmki. Lalu pelaporan didaerah kupang. Dan penambahan } \\
\text { pernyataan dari berbagai tokoh yang mempunyai kredibilitas dan pemuka } \\
\text { agama terkait. Jadi bisa dikatakan pada pemberitaan mengenai UAS kali } \\
\text { ini bersifat objektif dan dengan didukung oleh pernyataan dari orang- } \\
\text { orang yang berkredibilitas. Selain itu didalam berita tersebut termasuk ke } \\
\text { dalam berita yang tergolong cover both side. Mulai dari pihak yang } \\
\text { bersangkutan seperti Ustadz Abdul Somad, perwakilan dari kedua agama, } \\
\text { bahkan pihak netral yaitu ketua BPIP. }\end{array}$ \\
\hline Skrip & $\begin{array}{l}\text { Berita ini tergolong kedalam berita yang memiliki kelengkapan 5W+1H, } \\
\text { namun lebih menekankan pada what (apa) apa yang sedang terjadi, yaitu } \\
\text { pelaporan mengenai kasus penistaan agama yang oleh Ustadz Abdul } \\
\text { Somad. Selain itu kompas menekankan pada who (siapa) pihak yang } \\
\text { terkait yaitu pihak pelapor, terlapor dan beberapa pemuka agama yang }\end{array}$ \\
\hline
\end{tabular}




\begin{tabular}{|l|l|}
\hline & memberikan pernyataan. \\
\hline Tematik & $\begin{array}{l}\text { Kompas menggunakan kalimat "sebaiknya semua pihak tetap menjaga } \\
\text { suasana damai dan tetap menahan diri". Maksud kata menahan diri } \\
\text { Kompas mengkonstruksi berita agar audience tidak mudah terprovakasi } \\
\text { atau tetap menjaga perdamaian. }\end{array}$ \\
\hline Retoris & $\begin{array}{l}\text { Kompas TV mampu menambah penekanan berita dengan menampilkan } \\
\text { cuplikan video dan gambar. Mulai dari proses pelaporan, dibagian } \\
\text { tersebut dijelaskan bahwa UAS dilaporkan ke POLRI, Kompas TV } \\
\text { menampilkan surat laporan UAS yang bertuliskan perkara : penistaan } \\
\text { agama. Ketika Kompas TV mewawancarai pihak yang terkait, pihak } \\
\text { kompas juga melakukan wawancara secara on camera terhadap } \\
\text { narasumber terkait. }\end{array}$ \\
\hline
\end{tabular}

\section{Analisis Berita 3}

Nama program : Kompas Siang

Judul : Soal Ceramah Ustadz Abdul Somad, Polisi Kaji Laporan Dari Pelapor

Tabel 3. Analisis berita 3

\begin{tabular}{|l|l|}
\hline \multicolumn{1}{|c|}{ Struktur } & \multicolumn{1}{|c|}{ Analisis } \\
\hline Sintaksis & $\begin{array}{l}\text { Pada pemberitaan ini merupakan berita yang menonjolkan kelanjutan dari } \\
\text { pelaporan yang ditujukan kepada Ustadz Abdul Somad. } \\
\text { Terdapat beberapa kutipan: pertama, Brigjen Abdi Prasetyo "Soal } \\
\text { ceramah UAS, polisi kaji laporan dari pelapor. Berdasarkan kutipan } \\
\text { tersebut menjelaskan bahwa polisi tengah menindaklanjuti mengenai } \\
\text { laporan terkait. Kompas TV juga memberitakan bahwa setelah adanya } \\
\text { pelaporan mengenai kasus dugaan penistaan agama terjadi juga pelaporan } \\
\text { balik oleh Sugiarto atas dugaan pencemaran nama baik dan penyebaran } \\
\text { berita bohong. Didukung dengan kutipan penjelasan mengenai penjelasan } \\
\text { bahwa ceramah yang dilakukan sifatnya tertutup dan bukan untuk umum } \\
\text { hanya kalangan internal saja. Kompas TV juga memberikan kutipan dari }\end{array}$ \\
\hline
\end{tabular}




\begin{tabular}{|c|c|}
\hline & $\begin{array}{l}\text { Jusuf Kalla untuk memberikan keterangan untuk tetap menghormati satu } \\
\text { sama lain. Selain itu kutipan dari Zainut Tauhid (Wakil Ketua MUI) } \\
\text { memberikan penjelasan bahwa kasus pihak terkait agar diselesaikan } \\
\text { secara damai, karena hal-hal seperti ini dapat merusak keharmonisan. } \\
\text { Kemudian kutipan dari ketua PBNU memberikan keterangan bahwa } \\
\text { berdakwah sebaiknya tidak masuk ranah agama lain. Bahkan kompas } \\
\text { menambahkan kutipan dari ketua PGI yang memberikan keterangan } \\
\text { bahwa masalah ini bisa diselesaikan dengan dialog. Berdasarkan dari } \\
\text { beberapa kutipan yang ditampilkan beberapa narasumber yang memiliki } \\
\text { kredibilitas tinggi Kompas TV mampu mengkonstruksi bahwa kasus ini } \\
\text { merupakan kasus yang dapat diselasaikan secara damai dan baik-baik. }\end{array}$ \\
\hline Skrip & $\begin{array}{l}\text { Pada berita ini Kompas TV menekankan pada who (siapa) beberapa pihak } \\
\text { terkait yang memberikan keterangan dan how (bagaimana) yaitu cara } \\
\text { penyelesaian untuk menyelasaikan kasus ini. }\end{array}$ \\
\hline Tematik & $\begin{array}{l}\text { Kompas memilih menggunakan kalimat "menyinggung" bukan } \\
\text { menggunakan kata "menghina". Karena kata "menyinggung" dinilai lebih } \\
\text { sopan untuk pihak terlapor yang bahan statusnya belum dijadikan } \\
\text { tersangka untuk kasus penistaan agama. Disini terlihat bahwa Kompas } \\
\text { TV tidak menuduh terlapor secara langsung. }\end{array}$ \\
\hline Retoris & $\begin{array}{l}\text { Kompas TV memberikan penegasan dengan menampilkan keterangan } \\
\text { dari beberapa narasumber yang memiliki kredibilitas tinggi. }\end{array}$ \\
\hline
\end{tabular}

\section{Analisis Berita 4}

Nama program : Kompas Petang

Judul : Viral Ceramah Ustadz Abdul Somad, Ketua PGI : Kami Ingin Bertemu UAS, Kita Selesaikan Dengan Baik

Tabel 4. Analisis berita 4

\begin{tabular}{|l|c|}
\hline \multicolumn{1}{|c|}{ Struktur } & Analisis \\
\hline Sintaksis & Berita ini awalnya menyampaikan lima point yang disampaikan oleh \\
\hline
\end{tabular}




\begin{tabular}{|c|c|}
\hline & $\begin{array}{l}\text { Ustadz Abdul Somad. Selanjutnya menampilkan keterangan dari } \\
\text { perwakilan kedua pihak agama terkait. Pihak yang dimintai keterangan } \\
\text { secara live yaitu Marsudi Suhud (ketua MUI) walaupun Kompas Petang } \\
\text { tidak bisa mendatangkan ketua PGI secara langsung, pihak Kompas } \\
\text { memawancarai secara live on cam melalui Kompas Bandung bersama } \\
\text { ketua PGI. Ketua MUI memberikan keterangan bahwa MUI } \\
\text { menginginkan kasus UAS tak dibawa keranah hukum, hal serupa juga } \\
\text { disampaikan Ketua PGI, ia memberikan keterangan bahwa kasus ini } \\
\text { sangat bisa diselesaikan secara baik-baik, kerena masalah ini menyangkut } \\
\text { keutuhan bangsa. Kompas TV tidak menambahkan atau mengurangi } \\
\text { beberapa point yang disampaikan oleh Ustadz Abdul Somad. Kompas } \\
\text { menghadirkan kedua pihak yang merupakan ketua lembaga agama pihak } \\
\text { terkait. Dengan kata lain kompas mampu mengkonstruksi atau } \\
\text { membungkus berita ini yang bahkan orang-orang yang berkredibilitas } \\
\text { menginginkan diselesaikan secara baik-baik, jadi masyarakat bisa } \\
\text { memaknai bahwa hal ini dapat diselesaikan secara damai. }\end{array}$ \\
\hline Skrip & $\begin{array}{l}\text { Aspek yang ditekankan pada pemberitaan kali ini yaitu who (siapa) yaitu } \\
\text { menampilkan pihak-pihak yang berkredibilitas dan memberikan } \\
\text { pernyataan-pernyataan. Selain itu aspek yang ditekankan adalah how } \\
\text { (bagaimana) pihak-pihak tersebut memberikan penjelasan bagaimana cara } \\
\text { menyelesaikan masalah ini. }\end{array}$ \\
\hline Tematik & $\begin{array}{l}\text { Tidak ada struktur retoris dalam berita ini karena berita bersifat Live On } \\
\text { Cam sehingga berita lebih dominan menayangkan pernyataan narasumber } \\
\text { secara live. }\end{array}$ \\
\hline Retoris & $\begin{array}{l}\text { Pihak Kompas TV tidak memberikan penegasan apapun karena dalam } \\
\text { berita ini berita didominasi oleh pernyataan live dari narasumber tanpa } \\
\text { ditambah ataupun dikurangi. }\end{array}$ \\
\hline
\end{tabular}

\section{PENUTUP}

\section{Kesimpulan}

Berdasarkan hasil penelitian, dapat disimpulkan Kompas TV memberitakan dari awal pelaporan yang dilakukan oleh GMKI, hingga kelanjutan setelah pelaporan. Kompas 
TV membingkai dengan tidak memberatkan kesalah satu pihak atau tidak membela. Penambahan kutipan dari narasumber berkredibilitas yang mewakili agama terkait seperti Ketua MUI, Ketua PGI, Jusuf Kalla turut mendukung pemberitaan Kompas TV yang menunjukkan tanda netral. Beberapa narasumber mengatakan bahwa hal ini harusnya diselesaikan secara damai tanpa harus dibawa keranah hukum. Dengan menampilkan beberapa kutipan tersebut secara tidak langsung kompas mengkonstruksi pemberitaan ini sebagai berita yang tidak membuat perpecahan dimasyarakat. Dengan demikian pemberitaan Kompas TV mengenai kasus dugaan penistaan agama oleh Ustadz Abdul Somad tergolong berimbang dan tidak mewakili kepentingan tertentu.

\section{DAFTAR PUSTAKA}

Angga Dwi Pranata. (2018). Analisis Framing Pemberitaan Di Media Kompas Dan Jawa Pos (Analisis Framing Pemberitaan Ahok Dan Surat Al-Maidah Di Media Kompas Dan Jawa Pos Edisi Bulan November). http://eprints.ums.ac.id/61283/1/NASKAH\%20PUBLIKASI.pdf ( Diakses $12 / 09 / 19)$

Boby Tridona. (2016). Analisis Framing Pemberitaan Konflik Gubernur Dki Jakarta Dan Dprd Dki Jakarta Di Media Online (Analisis Framing Pada Media Online Kompas.com Dan Detik.com Periode 27 Februari - 10 Desember 2015). [Skripsi]. Universitas Lampung Bandar Lampung. http://digilib.unila.ac.id/22539/20/SKRIPSI\%20TANPA\%20BAB\%20PEMBAHAS AN.pdf ( Diakses 11/09/19)

Citra Hayati Nainggolan, S. Rouli Manalu, Ph.D. Analisis Framing Pemberitaan Ganjar Pranowo Dalam Kasus Korupsi E-KTP (Tribun News, Jawa Pos, dan Suara Merdeka periode Agusutus-Nobember 2015 dan Maret 2017). https://media.neliti.com/media/publications/184689-ID-analisis-framingpemberitaan-ganjar-pran.pdf ( diakses 10/09/19)

Eriyanto, (2002). Analisis Framing: Konstruksi, Ideologi, Dan Politik Media. Yogyakarta: Penerbit LkiS.

Eriyanto. (2005). Analisis Framing : Konstruksi, Ideologi, dan Politik Media. Yogyakarta : Lkis

Eriyanto. (2007). Analisis Framing : Konstruksi, Ideologi, dan Politik Media. Yogyakarta : Lkis

Ibrahim, S, I. (2011). Kritik Budaya Komunikasi (Cetakan I). Yogyakarta :Jalasutra Indra Adi Anggoro. (2017). Sikap Media Online Kompas.Com Terhadap Pemberitaan Basuki Tjahaja Purnama. https://media.neliti.com/media/publications/187031-ID-none.pdf ( Diakses 10/09/19)

Kreno, D. S. (2014). Kontruksi Sosial Pemberitaan Kasus Simulator SIM di Media Online Kompas.com

Kumala Citra Somara Sinaga, (2016). Analisis Framing Pemberitaan Bom Sarinah Di Kompas.Com Dan Merdeka.Com. Jom Fisip, Vol.3 No.2. 
https://media.neliti.com/media/publications/116185-ID-analisis-framingpemberitaan-bom-sarinah.pdf (diakses 10/09/19)

Muhamad khafidin. (2017). Framing Kasus Ahok Tentang Penistaan Agama ( Analisi Berita Kompas Edisi 5-17 November 2016 ). [Skripsi ]. Universitas Islam Negeri Sunan Kalijaga Yogyakarta.

http://digilib.uin-suka.ac.id/27130/1/13210120_BAB-I_IV-atau-V DAFTARPUSTAKA.pdf ( Diakses 11/09/19)

Muhammad Rizki Siregar, Agus Aprianti. (2017). Kasus Pernyataan Penistaan Agama Islam Oleh Gubernur Dki Jakarta Basuki Tjahaja Purnama (Analisis Model Framing Zhondang Pan Dan Gerald M Kosicki Pemberitaan Penetapan Ahok Menjadi Tersangka Penistaan Agama Islam Pada Tanggal 16 November 2016 Di Media Online Kompas.Com Dan Detik.Com). e-Proceeding of Management : Vol.4, No.3 https://openlibrary.telkomuniversity.ac.id/pustaka/files/137744/jurnal_eproc/kasuspernyataan-penistaan-agama-islam-oleh-gubernur-dki-jakarta-basuki-tjahajapurnama-analisis-model-framing-zhondang-pan-dan-gerald-m-kosicki-pemberitaanpada-tanggal-16-nov-2016-di-media-online-kompas-com-dan-detik-com.pdf ( Diakses 10/09/19)

Moleong, Lexy J. (2004). Metodologi Penelitian Kualitatif. Bandung: PT. Remaja Rosdakarya.

Yuva Naelana dan S. Bekti Istiyanto. (2019). Analisis SWOT Strategi Pengelolaan Reputasi PT. Cowboy Nusantara Jaya. Communications, Vol. 1 No. 2. http://journal.unj.ac.id/unj/index.php/communications/article/view/communications. $\underline{1.2 .3 / 7274}$ ( Diakses 10/09/19) 